\title{
14 \\ Pensions and the Modern Workforce
}

\author{
ALYSIA BLACKHAM*
}

\section{INTRODUCTION}

$\mathrm{O}$ LD AGE PENSIONS play a fundamental role in ensuring adequacy of income for the elderly into old age. While pensions fulfil a key social and economic role, there is increasing concern that pension systems in developed countries are not sustainable in the face of demographic ageing and following poor investment returns during the financial crisis. The UK, for example, is facing a recurrent 'pensions crisis': ${ }^{1}$ the number of people over the state pension age (SPA) is projected to increase by 28 per cent, from 12.2 million people in 2011 to 15.6 million people in 2035. People are living longer, and are therefore also likely to draw on pensions for a longer period; some will spend nearly a third of their life in retirement. ${ }^{3}$ National Insurance Fund expenditure on pensions is therefore expected to increase from around 5 per cent of GDP in 2008-09 to 8 per cent in 2070-71. ${ }^{4}$

In the face of these ongoing challenges to pension sustainability, there is an increasing move towards restructuring pension systems to ensure their long-term viability and to reduce exposure to demographic ageing. Pension reform is occurring

\footnotetext{
* This research was funded by the Australian government through the Australian Research Council's Discovery Projects funding scheme (project DE170100228). The views expressed herein are those of the author and are not necessarily those of the Australian Government or Australian Research Council.

${ }^{1} \mathrm{~J}$ Harris, 'The Roots of Public Pensions Provision: Social Insurance and the Beveridge Plan' in H Pemberton et al (eds), Britain's Pensions Crisis: History and Policy (Oxford, Oxford University Press, 2006) 34.

2 ONS, 'UK Population Projected to Reach 70 Million by Mid-2027' (2011): www.ons.gov.uk/ons/ $\mathrm{rel} / \mathrm{npp} /$ national-population-projections/2010-based-projections/sum-2010-based-national-populationprojections.html.

${ }^{3}$ MW Riley and JW Riley Jr, 'Age Integration and the Lives of Older People' (1994) 34 The Gerontologist 110, 110.

${ }^{4}$ Government Actuary's Department, 'Government Actuary's Quinquennial Review of the National Insurance Fund as at April 2005' (London, The Stationery Office 2010) 16. To put this in perspective, in 2009 public healthcare spending accounted for $8.2 \%$ of UK GDP (dropping slightly to $8.0 \%$ in 2010): U Qaiser, 'Expenditure on Healthcare in the UK' (London, The Stationery Office 2011) 4. This is projected to rise to $8.8 \%$ of GDP in 2062-63, with an additional $2.4 \%$ being spent on long-term care: Office for Budget Responsibility, 'Fiscal Sustainability Report' (London, The Stationery Office 2013) 80.
} 
or being contemplated at both governmental and pension fund level across OECD countries. This reform, however, is often undertaken in abstract and with limited consideration of broader employment trends, which themselves pose fundamental challenges to the future of pension systems. Reconciling labour law scholarship with scholarship on pensions is itself a major challenge for academic scholars.

This chapter takes up this challenge. Drawing on trends in pension law and policy in the UK and Australia, it commences with a discussion of how we might conceive of pensions from a theoretical perspective (part II), and considers the emerging challenges to established pension systems from the changing nature of work and social and demographic shifts (part III). The chapter argues that existing pension systems are not yet able to accommodate the changing nature of work, and puts forward normative criteria for evaluating and developing more appropriate pension systems for the modern workforce (part IV). It then maps emerging trends in pension reform (part $\mathrm{V})$, and considers the tensions that are playing out in trying to navigate these normative criteria. Part VI concludes.

\section{THEORETICAL UNDERSTANDINGS OF PENSIONS AND PENSION PROVISION}

How we normatively understand pensions is nationally and temporally dependent. Following the advocacy of the World Bank, national pension systems are increasingly moving towards 'three-tier' mixed pension systems, which combine basic state-based pay-as-you-go pensions (the first pillar) with funded occupational and individual supplements (the second and third pillars). ${ }^{5}$ The move towards a three-pillar structure decentres the role of governments to provide for pensions, and shifts responsibility towards private, funded pension solutions. ${ }^{6}$ The UK has embraced this approach wholeheartedly, adopting a clear three-tier model with a very low state basic pension as the first tier, and supplementary state, occupational and individual pension provision as the second and third tiers. In 2008-09, UK government pension benefits ${ }^{7}$ for a median earner constituted only 37 per cent of average UK earnings, representing one of the lowest replacement rates in the OECD. ${ }^{8}$ The UK is now significantly more reliant on private pension provision than other countries in Europe and the OECD. ${ }^{9}$

This shift towards private pension provision will also influence how we conceive of pensions from a normative perspective. Within this policy framework, old age pensions could be perceived in three key ways, depending on their structure and the form of pension provision.

\footnotetext{
${ }^{5}$ M Leimgruber, 'The Historical Roots of a Diffusion Process: The Three-Pillar Doctrine and European Pension Debates (1972-1994)' (2012) 12 Global Social Policy 24, 25.

6 ibid 26.

${ }^{7}$ Including the flat-rate basic pension plus any earnings-related additional pension and pension credit. However, the figure does not include mandatory or voluntary private pensions.

${ }^{8}$ OECD, 'Pensions at a Glance 2011: Retirement-Income Systems in OECD and G20 Countries' (2011) 118-19.

${ }^{9} \mathrm{~S}$ Diepeveen, 'Impact of the Recession on Age Management Policies: United Kingdom' (Dublin, Eurofound, 2012) 10.
} 
First, we could conceive of (government) pensions as a form of social right delivered by the government, to which individuals are entitled due to their citizenship and residency in a country. This view of pensions is most likely to be relevant to government provided basic pensions - that is, the first pillar - particularly where the scheme is unfunded and/or non-contributory.

Second, we could see pensions as a form of deferred wage, where individuals set aside their earnings to facilitate a later income in retirement. In this conception, individuals might be regarded as having proprietary or contractual rights and entitlements to a pension pay-out, at least to the extent to which that would be based on their earlier contributions and any related investment returns. ${ }^{10}$ This view is most likely to apply to the second and third pillars of pension provision, namely occupational and individual supplements.

Third, we can see pensions as a form of paternalistic gratuity, given either from the state or from employers. This sees pensions as essentially a gift, binding only in individual expectations and, perhaps, the potential for detrimental reliance based on the promise of the pension 'gift'. Thus, pension reform might be limited via a form of estoppel, either legally or at least in the public imagination.

The second view, of pensions as individual property rights, has been given substantial support by decisions relating to the European Convention on Human Rights. Article 1 of Protocol 1 to the Convention says:

Every natural or legal person is entitled to the peaceful enjoyment of his possessions. No one shall be deprived of his possessions except in the public interest and subject to the conditions provided for by law and by the general principles of international law.

The preceding provisions shall not, however, in any way impair the right of a State to enforce such laws as it deems necessary to control the use of property in accordance with the general interest or to secure the payment of taxes or other contributions or penalties.

This has been held to apply to old age pensions, even if they are non-contributory. For example, in Carson $v$ United Kingdom, ${ }^{11}$ the European Court of Human Rights held that

while there is no obligation on a State under Article 1 of Protocol No 1 to create a welfare or pension scheme, if a State did decide to enact legislation providing for the payment as of right of a welfare benefit or pension - whether conditional or not on the prior payment of contributions - that legislation had to be regarded as generating a proprietary interest falling within the ambit of Article 1 of Protocol No 1 for persons satisfying its requirements. ${ }^{12}$

Thus, individuals can have a proprietary interest in both contributory and noncontributory pension schemes, so long as they satisfy the legislative requirements.

\footnotetext{
${ }^{10}$ Supiot explicitly rejects the idea that pension systems are a 'contract between the generations': A Supiot, The Spirit of Philadelphia: Social Justice vs the Total Market (London, Verso, 2012) 131. According to Supiot, pension systems are 'incomprehensible' to contract law, given both the time frame and vertical axis on which obligations are based: ibid. Instead, pensions should be regarded as non-contractual obligations in response to the 'debt of life': ibid.

${ }^{11}$ Carson v United Kingdom 42184/05 (2010) 51 EHRR 13.

12 ibid [64]-[65].
} 
This broad reading of Article 1 is not without its critics: in $R$ (on the application of Carson) $v$ Secretary of State for Work and Pensions ${ }^{13}$ Lord Hoffmann opined that:

I must confess that my first instinct would not be to regard a social security benefit like a state pension as a possession until it had actually fallen due. But the European Court has developed a somewhat artificial jurisprudence on this question. It has clearly felt frustrated by the need to find a Convention pigeon hole into which to fit every objectionable form of discrimination. Social security benefits are a good example. In principle it does not seem at all unreasonable that in distributing public money in the form of social security benefits, the state should be obliged to treat like cases alike ... But the virtual absence of economic rights in the Convention has made it difficult to relate this principle to the enjoyment of any specified right. The preferred choice of the Strasbourg court in locating a Convention right in cases of economic discrimination by the state has been [Article 1 of Protocol 1]. In Müllerv Austria (1975) 3 DR 25 the Commission said that a claim to contributory benefits was a 'possession' by analogy with the proprietary right of a contributor to a private pension fund ... But the analogy is weak because (at any rate in the United Kingdom) contributions are hardly distinguishable from general taxation, the 'fund' exists purely as a matter of public accounting and no one is entitled to anything beyond that which the legislation may from time to time prescribe. The Strasbourg court has been obliged to accommodate this state of affairs by saying that although a claim to a social security benefit is a possession ... it does not entitle one to anything in particular. ${ }^{14}$

In this case, then, Lord Hoffmann assumed that the pension rights in question were a 'possession' for the purposes of Article $1 .{ }^{15}$ Thus, while the Convention may mean that individuals have a right to an old age pension as a 'possession', this does not equate to any particular quantum of money. ${ }^{16}$ This 'right' therefore stands in stark contrast to traditional ideas of property rights at common law.

\section{CHALLENGES TO PENSION SYSTEMS FROM THE CHANGING NATURE OF WORK}

Regardless as to how pensions are conceived, they are under substantial and sustained challenge from the changing nature of work and the decline of the traditional male breadwinner norm. These challenges are originating from growing job mobility and international mobility, work precarity, women's workforce participation and the gender pension gap, and demographic ageing. Each of these challenges is mapped in turn.

\section{A. Job Mobility}

Job mobility is increasing in the modern workforce. This reflects a growth in work precarity, the decline of the 'job for life', and increasing job-to-job transitions.

\footnotetext{
${ }^{13} R$ (on the application of Carson) $v$ Secretary of State for Work and Pensions [2005] UKHL 37, [2005] 2 WLR 1369.

${ }^{14}$ ibid [11]-[12] (Lord Hoffmann).

${ }^{15}$ See also ibid [84] (Lord Walker), [95] (Lord Carswell).

${ }^{16}$ See the detailed discussion in Carson v Secretary of State for Work and Pensions [2003] EWCA Civ 797, [2003] 3 All ER 577, [17]-[23] (Laws LJ).
} 
For example, Gregg and Wadsworth argue that job stability declined in Britain for the majority of the workforce between 1975 and 2000, and for those without dependent children in particular. ${ }^{17}$ Around a quarter of this trend was attributable to the changing nature of work, such as a shift to part-time work, temporary jobs and self-employment. ${ }^{18}$ The decline in long-term jobs (that is, those that last over 10 years) was particularly concentrated among men over the age of $50 .{ }^{19}$ However, the authors concluded that the most likely explanation for the decline in job tenure was a growth in job-to-job mobility across the workforce. ${ }^{20}$

Growing job mobility makes pensions tied to one particular employer increasingly unsuitable for the modern workforce, and poses a particular challenge to occupational pensions. Indeed, requiring an extended period of service at one employer to receive an old age pension, and prohibiting workers from transferring their benefits to a new scheme, can seriously affect job mobility. ${ }^{21}$ While this may actually have been one of the intentions of those establishing occupational pensions for particular employers, as a means of increasing job tenure and loyalty, it is likely to be inappropriate for a global and mobile workforce. ${ }^{22}$ The move to personal - and portable pension arrangements may address these issues to some extent. However, it means that employees may have to decline more generous occupational pension schemes which reduce mobility - if they wish to move jobs later on. This is likely to reduce individual pension savings overall. ${ }^{23}$

\section{B. International Mobility}

At a broader level, pension mobility across national borders is an emerging issue for the modern workforce. The International Labour Organization (ILO) estimates that there are 150.3 million migrant workers worldwide, comprising 4.4 per cent of all workers. ${ }^{24}$ Nearly 80 per cent of migrant workers are located in high-income countries such as Australia and the UK. ${ }^{25}$ While high-income countries often have well-developed social protection systems, encompassing areas such as healthcare, pensions and other forms of social security, there is growing concern regarding the extent to which migrant workers have entitlements to these social benefits.

\footnotetext{
${ }^{17}$ P Gregg and J Wadsworth, 'Job Tenure in Britain, 1975-2000. Is a Job for Life or Just for Christmas?' (2002) 64 Oxford Bulletin of Economics \& Statistics 111, 132.

18 ibid.

19 ibid.

${ }^{20} \mathrm{ibid}$.

${ }^{21}$ cf Disney and Emmerson, who argue that workers take subsequent job mobility into account when choosing their pension arrangements, if the occupational pension offered does not facilitate mobility: R Disney and C Emmerson, 'Choice of Pension Plan and Job Mobility in Britain' (Discussion Paper, Sydney, 23 July 2004). This implies that individuals will take a less generous pension arrangement that offers mobility, if they intend to leave their job in the future.

${ }^{22}$ JA Turner et al, Pension Policy for a Mobile Labor Force (Kalamazoo, MI, Upjohn Press, 1993).

${ }^{23}$ Of course, this is something of a moot point, given the closure of many occupational pension schemes to new entrants. See below.

${ }^{24}$ ILO, 'ILO Global Estimates on Migrant Workers: Results and Methodology' (2015) xi, 8-10.

25 ibid xiv, 8-10.
} 
Pensions - and old age pensions in particular - pose particular challenges for migration. First, old age pension entitlements are highly nation-specific, meaning it is difficult to simply transfer entitlements between countries. Indeed, while high-income countries often have generous and well-developed social security systems, low-income countries often make no provision for old age pensions. Thus, it is difficult (if not impossible) to simply transfer entitlements between jurisdictions, particularly where migrants are moving between high- and low-income countries.

Second, in high-income countries, pensions can constitute a significant proportion of governmental expenditure, meaning there is limited appetite to extend pension coverage to new entrants, ${ }^{26}$ and migrants in particular. This is particularly challenging in an era where there is a backlash generally against migration, including in Europe.

Third, pension entitlements are often built up over a significant period of time, and may be subject to citizenship and residency requirements. Temporary labour migration may prevent individuals from satisfying these requirements, undermining social protection. ${ }^{27}$ Thus, migration challenges the very founding principles of some social security regimes.

Fourth, ensuring effective pension portability for migrant workers as they move between countries raises the need for extensive intergovernmental cooperation and agreement between the countries of origin and destination, as well as needing supportive domestic legislation. This adds a substantial additional hurdle for securing pension portability, as it is largely dependent on political appetite for cooperation and reform.

In practice, Holzmann and Koettl have identified four different pension portability regimes:

1. Portability, where all migrants have access to pensions benefits. This is often secured via bilateral or multilateral agreements with other countries, and is most often seen in the European Union (EU), and between high income countries. This situation applies to approximately 23 per cent of migrant workers, who are mostly EU-27 migrants.

2. Exportability, where migrants are entitled to benefits in their host countries, but there is no agreement between the host country and the country of origin. Thus, migrants cannot have a totalisation or consolidation of their contribution periods to the social security system, meaning there may be issues when a migrant leaves the host country. This affects around 55 per cent of migrants.

3. Access exclusion, where migrants do not have access to social benefits in their host country, either because they are not allowed to join the system, or because there is no system at all. This affects approximately 5 per cent of migrants globally. ${ }^{28}$

\footnotetext{
${ }^{26}$ See, eg, ILO, 'Towards a Fair Deal for Migrant Workers in the Global Economy' (2004) 35.

27 ibid 77.

${ }^{28} \mathrm{Or}$, perhaps, migrants might be excluded from social security systems even when they are entitled to join them, such as where migrants are employed as 'contractors' to avoid employment obligations: B Xiang, 'Structuration of Indian Information Technology Professionals' Migration to Australia: An Ethnographic Study' (2001) 39 International Migration 73.
} 
4. Informality, for undocumented migrants, which affects around 18 per cent of migrants globally. ${ }^{29}$ Informal migrants are likely excluded from any social security provision, and experience a host of other employment issues.

This demonstrates that regimes for pension portability are highly context- and country-specific, and change frequently as government priorities shift. For migrants outside the EU, pension portability is generally unattainable, and labour migration has a significant deleterious effect on pension provision. Given the global absence of portability, there is a growing concern in the literature for how social benefits might limit or deter labour mobility, ${ }^{30}$ both within and between countries. Unsurprisingly, difficulties in the transfer of social security benefits appear to deter mobility in the European context. ${ }^{31}$

Beyond this impact on individual mobility, pension portability also has significant implications for social risk management and the structural sustainability of pension systems. While work on pension mobility between EU countries, as part of the literature on the free movement of persons, has started to consider the possible impacts of mobility on pension systems themselves, ${ }^{32}$ this discussion has not extended beyond the EU. It is clear, however, that labour migration raises pension risks for both individuals and nation states. If migrants lack pension benefits, or cannot port their benefits upon moving, this puts them at risk of poverty in old age, particularly if they are in low-paid work. Where pensions are dependent on workers' own contributions to the scheme ('contributory'), worker migration can lead to underinsurance in old age, particularly when migrant workers change country ${ }^{33}$ or have unstable labour market biographies. ${ }^{34}$ Relatedly, pension mobility or immobility is a key factor in the passing of social risks between national governments. If pensions are not portable, this will likely lead to a financial windfall to the country the migrant worker is leaving, which will no longer be responsible for the workers' welfare in retirement, but which benefited from their skills and contribution during their working life, and create an additional financial burden to the migrant's new country, which may become liable to support the migrant worker into old age. ${ }^{35}$ Thus, if there is no redistribution or portability of pension rights, this will increase social risks, ${ }^{36}$ both for individuals and for their destination country. This is particularly problematic if temporary

\footnotetext{
${ }^{29} \mathrm{R}$ Holzmann and J Koettl, 'Portability of Pension, Health, and Other Social Benefits: Facts, Concepts, and Issues' (2015) 61 CESifo Economic Studies 377, 382 (Table 1).

${ }^{30}$ AC d'Addio and MC Cavalleri, 'Labour Mobility and the Portability of Social Rights in the EU' (2015) 61 CESifo Economic Studies 346; R Holzmann and M Werding, 'Portability of Social Benefits: Research on a Critical Topic in Globalization' (2015) 61 CESifo Economic Studies 335.

${ }^{31} \mathrm{~d}$ 'Addio and Cavalleri (n 30).

${ }^{32}$ A Jousten and P Pestieau, 'Labor Mobility, Redistribution, and Pension Reform in Europe' in M Feldstein and H Siebert (eds), Social Security Pension Reform in Europe (Chicago, IL, University of Chicago Press, 2002).

${ }^{33}$ P Frericks, 'Funded Pensions and Their Implications for Women and Migrant Workers' (2012) 12 Global Social Policy 342, 343.

${ }^{34}$ ibid.

${ }^{35}$ R Holzmann and J Koettl, 'Portability of Pension, Health, and Other Social Benefits: Facts, Concepts, Issues' (IZA DP, Bonn, May 2011) 11; Holzmann and Koettl (n 29) 8.

${ }^{36}$ Frericks (n 33) 343.
} 
migrant workers are spending time in high-income countries during their working lives, but returning to low-income countries in their later years, as this will likely lead to a transfer of wealth away from the low-income countries where it is most needed. Further, if migrant workers are returning to low-income countries which do not have adequate social security provision, they will be at an increased risk of poverty in old age. Thus, adequacy of pensions in old age fundamentally depends on transferability between countries. ${ }^{37}$

\section{Work Precarity}

Precarious work is of growing concern in the modern workplace. ${ }^{38}$ 'Precarious' work is that which 'departs from the normative model of the standard employment relationship ... and is poorly paid and incapable of sustaining a household'. ${ }^{39}$ The GMB union estimates that up to 10 million workers in Britain - nearly a third of the UK workforce - are in precarious employment, including those in the gig economy, on zero- or short-hours contracts, temporary workers, underemployed or at risk of false self-employment. ${ }^{40}$ Thus, precarious work is a growing feature of the modern workforce.

Precarious work challenges established pension systems in a number of compelling ways. First, precarious work is often associated with lows level of income; indeed, level of income is one of Rodgers's dimensions of work precarity, ${ }^{41}$ and Vosco defines 'precarious employment' as that characterised by low income. Workers with low income are unlikely to be able to consider saving for their future retirement or, indeed, may never be in a financial position to 'choose' to retire. Those on very low incomes may fall below the minimum income for making contributions to statutory pension schemes, reducing their ultimate pension entitlements. For example, pension 'automatic enrolment' under the Pensions Act 2008 (UK) only requires employers to enrol workers into a workplace pension scheme if they earn more than $£ 10,000$ per annum in 2018-19 from that employer. This will not capture those who are in very low paid positions, or those working for multiple employers at once. Workers with periods in and out of employment and with broken work histories will also have substantially reduced pension savings.

\footnotetext{
37 ibid.

${ }^{38} \mathrm{~S}$ McKay et al, 'Study on Precarious Work and Social Rights' (London, Working Lives Research Institute, 2012) 14.

${ }^{39}$ J Fudge and RJ Owens, 'Precarious Work, Women and the New Economy: The Challenge to Legal Norms' in J Fudge and RJ Owens (eds), Precarious Work, Women and the New Economy: The Challenge to Legal Norms (Oxford, Hart Publishing 2006) 3; see also LF Vosko, Managing the Margins: Gender, Citizenship, and the International Regulation of Precarious Employment (Oxford, Oxford University Press, 2010) 2; G Rodgers, 'Precarious Work in Western Europe: The State of the Debate' in G Rodgers and J Rodgers (eds), Precarious Jobs in Labour Market Regulation: The Growth of Atypical Employment in Western Europe (Brussels, International Institute for Labour Studies, 1989) 3.

${ }^{40}$ S Butler, 'Nearly 10 Million Britons Are in Insecure Work, Says Union' The Guardian (5 June 2017), available at: www.theguardian.com/business/2017/jun/05/nearly-10-million-britons-are-in-insecure-worksays-union.

${ }^{41}$ Rodgers (n 39) 3.
} 
Second, precarious workers on zero- or short-hours contracts, undertaking temporary and casual work or who are 'self'-employed may not fall within the scope of existing pension schemes and rules, which typically capture 'employees'. ${ }^{42}$ Pension provision for the 'self-employed' in particular is haphazard in many EU countries, and often relies on workers self-declaring their earnings and apportioning their own pension savings, posing a risk that workers may have insufficient funds in retirement. ${ }^{43}$ Further, precarious workers are unlikely to have access to most occupational pension funds, even if they had sufficient earnings to make contributions.

Third, precarious work is increasingly concentrated among young workers. ${ }^{44}$ The Resolution Foundation estimates that 37 per cent of those on zero-hours contracts are between 16 and 24 years of age. ${ }^{45}$ Over 40 per cent of employees under 30 are employed in low-wage jobs, compared with 14.68 per cent of those aged 30 to $49 ; 46$ and only 68 per cent of those aged under 35 are employed on an indefinite contract, compared with 85.7 per cent for those aged 36 to $49 .{ }^{47}$ This poses a challenge to the sustainability of unfunded pension systems that have traditionally relied on contributions from younger workers to fund the pensions of the elderly. If younger workers are not occupying well-paid jobs, or making contributions to pension schemes, they are unlikely to be able to finance the pensions of a sizable cohort of older workers.

Fourth, employers' growing reliance on a pool of precarious workers has gone hand-in-hand with the closure of occupational pension schemes to new entrants. If employers are increasingly relying on a precarious and transitory pool of workers, there is less need to offer incentives for employee retention and loyalty. Kilpatrick has described the 'truly spectacular flight away' from defined benefit (DB) pension schemes ${ }^{48}$ in the UK private sector: ${ }^{49}$ at 31 March 2011, only 16 per cent of DB occupational schemes were open to new members. ${ }^{50}$ Some employers instead offer their employees DC pension schemes, shifting the risks of longevity and investment returns to the individual. ${ }^{51}$ Other employers ceased to make any provision for employees'

\footnotetext{
42 Though the Pensions Act 2008 applies to the broader category of 'workers': s 1(1).

${ }^{43}$ C Barnard and A Blackham, 'Self-Employed: The Implementation of Directive 2010/41 on the Application of the Principle of Equal Treatment between Men and Women Engaged in an Activity in a Self-Employed Capacity' (Luxembourg, Publications Office of the European Union, 2015).

${ }^{44}$ See RM Carmo et al, 'Time Projections: Youth and Precarious Employment' (2014) 23 Time \& Society 337.

${ }^{45}$ M Pennycook et al, 'A Matter of Time: The Rise of Zero-Hours Contracts' (Resolution Foundation, 2013) 10 .

${ }^{46}$ Eurostat Structure of Earnings Survey, 2010.

${ }^{47}$ Fifth European Working Conditions survey, 2010

${ }^{48}$ Defined benefit or salary-related pension schemes pay pensions based on individuals' pensionable earnings and years of service. The schemes pay a guaranteed pension upon retirement, irrespective of investment returns. In contrast, in defined contribution (DC) schemes individuals build up a pension 'pot' which may be used to purchase an annuity upon retirement. The level of pension is not guaranteed and is linked to investment returns.

${ }^{49} \mathrm{C}$ Kilpatrick, 'The New UK Retirement Regime, Employment Law and Pensions' (2008) 37 Industrial Law Journal 1, 21.

${ }^{50}$ The Pensions Regulator, 'Annual Report and Accounts 2010-2011' (London, The Stationery Office, 2011) 15.

${ }^{51} \mathrm{D}$ Hirsch, 'Crossroads after 50: Improving Choices in Work and Retirement' (York, Joseph Rowntree Foundation, 2003) 7; P Thornton, 'A Note on the Investment Management of Defined Contribution Schemes' in P Thornton and D Fleming (eds), Good Governance for Pension Schemes (Cambridge, Cambridge University Press, 2011).
} 
pensions: the 2009 Employers' Pension Provision Survey of 2,519 UK organisations found only 28 per cent were making any provision for pensions (down from 41 per cent in 2007), and occupational pensions were being offered by only 2 per cent of private sector employers (down from 5 per cent in 2007). ${ }^{52}$ This decline may be addressed, in part, by auto-enrolment under the Pensions Act 2008. However, the level of saving required by auto-enrolment is unlikely to address chronic issues of 'under-saving' for retirement. ${ }^{53}$

Precarious work is therefore a serious challenge to pension adequacy, particularly given how widespread precarity has become in the modern workforce. Precarious work can undermine reliance on individual saving, occupational pensions and government contributory pension schemes. Thus, it is a substantial risk facing established pension arrangements. If not addressed via pension reform, precarious work could lead to a substantial increase in the number of pensioners in poverty in years to come, and increasing demand for other government services and support. Thus, precarious work will have substantially deleterious effects on both individual and societal financial wellbeing, now and in the future.

This is particularly problematic given pension adequacy was already a major concern. The move towards privatising and individualising pension risk through reliance on DC pension schemes has seen a significant decline in pension assets with the financial crisis and shocks to the stock market. This has generated concerns in relation to both the adequacy and sustainability of individual pension schemes, ${ }^{54}$ and has flagged the need to better regulate private pensions, both to address declining pension values, and to better protect individuals against the risks of the market. ${ }^{55}$ As it stands, however, private pension provision in the UK is well below that required to avoid individual poverty and ensure adequacy of income for retirees: according to 2012 figures, 10.7 million individuals in Great Britain are likely to have inadequate income in retirement. ${ }^{56}$ Thus, the growth in precarious work is building on a system where pension adequacy was already doubtful.

\section{Women's Workforce Participation}

Older women are less likely to participate in the workforce than older men, though participation rates are slowly increasing. ${ }^{57}$ Further, women (especially those with

\footnotetext{
52 J Forth and L Stokes, Employers' Pension Provision Survey 2009 (London, The Stationery Office, 2010) $15-16$.

${ }^{53}$ Select Committee on Public Service and Demographic Change, Ready for Ageing? (HL 2012-13, 140) 10. Individuals may also 'opt out' from the scheme, which may reduce its effectiveness.

${ }^{54}$ A Zaidi, 'Sustainability and Adequacy of Pensions in EU Countries: A Cross-National Perspective' (European Centre for Social Welfare Policy and Research, September 2010); J Draxler and J Mortensen, 'Towards Sustainable But Still Adequate Pensions in the EU: Theory, Trends and Simulations' (ENEPRI Research Report, April 2009).

${ }^{55} \mathrm{~B}$ Ebbinghaus and $\mathrm{T}$ Wiß, 'Taming Pension Fund Capitalism in Europe: Collective and State Regulation in Times of Crisis' (2011) 17 Transfer: European Review of Labour and Research 15.

${ }^{56}$ Select Committee on Public Service and Demographic Change (n 53) 7.

${ }^{57} \mathrm{See}$, eg, Australian Institute of Health and Welfare, 'Older Australia at a Glance, Employment \& Economic Participation’ (September 2018), available at: www.aihw.gov.au/reports/older-people/olderaustralia-at-a-glance/contents/social-economic-engagement/employment-economic-participation.
} 
caring responsibilities) are more likely to have disjointed careers than men, with periods in and out of the workforce. In addition to the gender pay gap, this has also led to a substantial gender pension gap.

In Australia, for example, according to the Association of Superannuation Funds of Australia, average superannuation balances for women at retirement (that is, for those aged 60-64) are 42 per cent lower than those for men. The median superannuation balance is three times higher for men than women (see Table 1). ${ }^{58}$ The fact that median superannuation account balances are so much lower than average account balances reflects the substantial number of Australians with no or very little superannuation. In 2015-16, around 32.7 per cent of women reported having no superannuation, compared with 27 per cent of men. ${ }^{59}$ The dramatic difference between the mean and median figures for women aged 60-64 indicates that some women have excellent superannuation provision; however, the vast majority have none, or very little.

Table 1 Superannuation account balances by age and gender, 2015-16, Australia

\begin{tabular}{|l|c|c|c|c|}
\hline Age & \multicolumn{2}{|c|}{ Male } & \multicolumn{2}{c|}{ Female } \\
\hline & Mean & Median & Mean & Median \\
\hline $30-34$ & $\$ 43,583$ & $\$ 30,000$ & $\$ 33,748$ & $\$ 23,396$ \\
\hline $60-64$ & $\$ 270,710$ & $\$ 110,000$ & $\$ 157,049$ & $\$ 36,003$ \\
\hline
\end{tabular}

The Association of Superannuation Funds of Australia estimates that to achieve a 'modest' standard of living in retirement, individuals need superannuation savings of $\$ 70,000 .{ }^{60}$ Few women in Australia will achieve even this modest standard of living in retirement. Thus, concerns about pension adequacy are particularly acute for women.

These concerns are compounded by two social trends. First, women tend to retire earlier than men - for example, in Australia, the average age at retirement from the labour force for persons aged 45 years and over in 2016-17 was 55.3 years, being 58.8 years for men and 52.3 years for women. ${ }^{61}$ For women retirees, 46 per cent had retired at an age earlier than 55; 39 per cent between the ages of 55 and 64; and only 15 per cent aged 65 and over. However, the average age at retirement for recent retirees (who had retired in the last five years) was 62.9 years. For this group, retirement ages were similar for women and men, with average retirement ages of 63.6 years for men and 62.1 years for women. Thus, women may be retiring later over time. ${ }^{62}$

Second, exacerbating the gender pension gap, women on average live longer than men, meaning their pensions also need to stretch for a longer period of time. In 2017 in Australia, women constituted 51 per cent of those aged 65-74, 54 per cent

\footnotetext{
${ }^{58} \mathrm{R}$ Clare, 'Superannuation Account Balances by Age and Gender' (Association of Superannuation Funds of Australia, October 2017), available at: www.superannuation.asn.au/ArticleDocuments/359/1710_ Superannuation_account_balances_by_age_and_gender.pdf.aspx?Embed=Y.

${ }^{59} \mathrm{ibid}$.

${ }^{60}$ Association of Superannuation Funds of Australia, 'ASFA Retirement Standard Summary 2018' (2018) 4.

${ }^{61}$ ABS 2017. 6238.0 - Retirement and Retirement Intentions, Australia, July 2016 to June 2017.

62 ibid.
} 
of those aged 75-84, and 63 per cent of those aged 85 and over. ${ }^{63}$ Thus, inadequate pension entitlements will be even more problematic for women than for men, over a longer time period. Current contributory pension arrangements do not recognise or accommodate women's disrupted career paths and unequal caring responsibilities.

\section{E. Demographic Ageing}

Demographic ageing is another obvious challenge facing established pension systems in all developed countries. In Australia, for example, in 2017 there were 3.8 million people aged 65 years and over, amounting to 15 per cent of the country's total population. ${ }^{64}$ By 2057, it is projected that this will rise to 8.8 million people, or 22 per cent of the population, and, by 2097, 12.8 million people or 25 per cent of the population. ${ }^{65}$ Thus, older people represent a growing proportion of the national population.

Further, those in this cohort are living longer lives, meaning 'older people' are, on average, getting older. In 2017, the majority (57 per cent, or 2.2 million) of older people in Australia were aged 65-74, one-third (30 per cent, or 1.2 million) were aged 75-84, and 13 per cent $(497,000)$ were aged 85 and over. ${ }^{66}$ By 2047, this is projected to shift substantially towards the older demographic, with those over 75 (those aged 75-84: 35 per cent or 2.6 million; those aged 85 and over: 20 per cent, or 1.5 million) outnumbering those aged between 65 and 74 (3.4 million people, or 45 per cent).

These shifts represent a triumph of modern medicine, with people, on average, living longer and healthier lives. However, they pose fundamental challenges to the sustainability of existing pension systems and the labour force more generally. If retirement ages remain static, there will be a growing cohort of retirees drawing on a pension, who are living for many more years than was originally envisaged. The success story of demographic ageing, then, comes with a financial cost.

Demographic ageing may challenge the fundamental assumptions of existing pension arrangements. Pension systems in Europe have traditionally been grounded in norms of intergenerational solidarity. This has served to justify and rationalise intergenerational transfers and redistribution where required to support adequacy of income, including through the pension system. Supiot defines solidarity as a way of conceiving a collective obligation not based on individual consent, family ties or community allegiance. ${ }^{67}$ More specifically, intergenerational solidarity involves 'each generation recognis[ing] its responsibilities towards the others' ${ }^{68}$ and a degree of

\footnotetext{
${ }^{63}$ Australian Institute of Health and Welfare, 'Older Australia at a Glance, Australia's Changing Age \& Gender Profile’ (September 2018), available at: www.aihw.gov.au/reports/older-people/older-australia-ata-glance/contents/demographics-of-older-australians/australia-s-changing-age-gender-profile.

${ }^{64}$ ibid.

65 ibid.

${ }^{66}$ ibid.

${ }^{67}$ A Supiot, Homo Juridicus: On the Anthropological Function of the Law (London, Verso, 2007) 208.

${ }^{68}$ Eurofound, 'Foundation Findings: Intergenerational Solidarity' (Luxembourg, Eurofound, 2012) 3.
} 
bonding between individuals of different age groups. ${ }^{69}$ Intergenerational solidarity is a form of 'contract across generations', ${ }^{70}$ with shared expectations and obligations around ageing and the 'succession of generations' ${ }^{71}$ grounded in the idea of reciprocity ${ }^{72}$ and intergenerational transfers. ${ }^{73}$ Intergenerational solidarity is therefore a form of social cohesion between generations. ${ }^{74}$

While intergenerational solidarity might have previously supported redistributional pension structures, this social cohesion is increasingly being challenged with demographic ageing and increasing youth unemployment and underemployment during the crisis. Supiot argues that solidarity in Western states is undergoing 'a major crisis', ${ }^{75}$ and there are calls for the UK to reconceive the nature of its 'intergenerational contract'. ${ }^{76}$ According to Bengtson and Oyama, intergenerational norms and the sense of reciprocity between age groups are changing as younger generations receive fewer financial succession benefits from older generations and there is increased geriatric dependency. ${ }^{77}$ As individuals live for longer and the population ages, a greater proportion of social goods will be consumed by older generations. In this context, Bengston and Oyama question whether norms of reciprocity between generations are still intact at the macro level, and flag the possibility that perceptions of 'generational inequity' may increase with time. ${ }^{78}$ This may reduce the acceptability of intergenerational transfers occurring within pension systems. Indeed, intergenerational solidarity may be disrupted by dissimilar interests between generations and conflicts around the distribution of social assets and equity ${ }^{79}$ Intergenerational solidarity may now require the 'acceptance of changed expectations among workers about when and how they leave the labour market' to extend working lives ${ }^{80}$ and reduce demand on pension systems. Intergenerational solidarity may therefore now require and justify pension reform, to reflect changing social expectations about retirement and levels of social support.

\footnotetext{
${ }^{69}$ MA Cruz-Saco, 'Intergenerational Solidarity' in MA Cruz-Saco and S Zelenev (eds), Intergenerational Solidarity: Strengthening Economic and Social Ties (New York, Palgrave Macmillan, 2010) 9.

${ }^{70}$ As noted above, Supiot explicitly rejects this idea: The Spirit of Philadelphia (n 10) 131.

${ }^{71}$ VL Bengtson and PS Oyama, 'Intergenerational Solidarity and Conflict' in MA Cruz-Saco and S Zelenev (eds), Intergenerational Solidarity: Strengthening Economic and Social Ties (New York, Palgrave Macmillan, 2010) 38.

${ }^{72}$ M Izuhara, 'Introduction' in M Izuhara (ed), Ageing and Intergenerational Relations: Family Reciprocity from a Global Perspective (Bristol, Policy Press 2010) 5.

${ }^{73}$ Bengtson and Oyama (n 71) 36; A Lowenstein, 'Determinants of the Complex Interchange among Generations: Collaboration and Conflict' in MA Cruz-Saco and S Zelenev (eds), Intergenerational Solidarity: Strengthening Economic and Social Ties (New York, Palgrave Macmillan, 2010) 58. At the same time, it is clear that individuals will have differing opinions on how the intergenerational contract should operate: Izuhara (n 72) 5.

${ }^{74}$ Bengtson and Oyama (n 71) 35.

${ }^{75}$ Supiot, Homo Juridicus (n 67) 209.

${ }^{76}$ DM Butts, 'Key Issues Uniting Generations' in MA Cruz-Saco and S Zelenev (eds), Intergenerational Solidarity: Strengthening Economic and Social Ties (New York, Palgrave Macmillan, 2010) 94.

${ }_{77}$ Bengtson and Oyama (n 71) 38-39.

${ }_{78}$ ibid 46-47.

${ }^{79}$ Cruz-Saco (n 69) 11.

${ }^{80}$ Eurofound (n 68) 3; see also Butts (n 76) 94.
} 


\section{NORMATIVE CRITERIA FOR DEVELOPING MORE APPROPRIATE PENSION SYSTEMS FOR THE MODERN WORKFORCE}

Old age pensions therefore raise a number of legal and normative tensions, and need to be considered from a number of angles. More particularly, normative evaluation of pension systems - and consideration of their future development - needs to take into account:

1. The viability of government, occupational and individual pension systems.

2. Adequacy of income for retirees.

3. Respect for individual property rights.

4. Fairness between generations, both in terms of contributions (whether via taxation or direct payments) and pay-outs.

5. Fairness within generations, including on the basis of class or socio-economic status and gender.

6. Portability within and across national borders.

These normative principles and ideals create a complex web of interlinked rights, responsibilities and expectations, which need to be carefully managed throughout the process of reform. To make this even more complex, pensions are situated in the public imagination, and seen by some as an entitlement and 'right'. Thus, any change or deviation from the status quo may be seen as an attack on individuals and a certain vision of society.

More generally, these normative principles also flag fundamental tensions in how we conceive of the role of pensions, and their fundamental rationale. For example, what counts as 'fair' in an intergenerational and intragenerational context? Should pension systems advance redistributional aims (either between or within generations) and, relatedly, to what extent should we expect individuals to support each other via the pension system? At what level of funding will a pension system become 'viable' and, conversely, what level of underfunding is 'unviable'? What quantum of pension income is required for an 'adequate' level of income? ${ }^{81}$ Our answers to these questions will be socially and culturally contingent, and are likely to vary across the political spectrum: there are no clear-cut or true-false answers to these issues. While recognising the complexity of all of these issues, two criteria require further exploration here: intergenerational fairness, and portability.

\section{A. Intergenerational Fairness}

At a base level, we need to think about how we can best conceptualise 'intergenerational fairness', and what this means in relation to pension contributions and pension pay-outs. Intergenerational fairness could be seen in a variety of ways:

- ensuring pension benefits are commensurate or proportional to the level of contributions (either from taxation or directly from salary) made by individuals over the life course (consistent with a contractual or deferred salary model);

\footnotetext{
${ }^{81}$ See, eg, AG Grech, 'How Best to Measure Pension Adequacy' (Centre for Analysis of Social Exclusion, 2013).
} 
- securing adequacy of income for all generations in retirement (a social right or paternalistic gratuity model);

- ensuring a similar level of pension payments for individuals of all ages (again, consistent with a social right or paternalistic gratuity model); and/or

- matching individual expectations of the level of pension provision they will obtain in retirement (either derived from past behaviour and contractual entitlements, or from the social or employment contract).

These forms of fairness are likely consistent with the various ways of conceiving of pensions (see part II above). However, achieving most of these conceptions of 'fairness' is likely to seriously jeopardise the sustainability of pension systems. Further, some forms of fairness are easier to achieve than others - for example, the first idea of commensurability or proportionality is best achieved via individual funded pension accounts, where it is clear what individuals have contributed over the life course and the present-day value of those contributions. However, commensurability or proportionality does not necessarily secure adequacy of income, as the discussion of the gender pension gap shows, and is difficult to determine in unfunded, noncontributory or communal pension schemes.

It is clear that this balance between intergenerational and intragenerational fairness, sustainability and adequacy of income in governmental pension reform is an area of significant concern in the UK. In practice, young workers are often disadvantaged in pension provision. Under Article 6(2) of the Framework Directive:

Member States may provide that the fixing for occupational social security schemes of ages for admission or entitlement to retirement or invalidity benefits, including the fixing under those schemes of different ages for employees or groups or categories of employees, and the use, in the context of such schemes, of age criteria in actuarial calculations, does not constitute discrimination on the grounds of age, provided this does not result in discrimination on the grounds of sex.

The UK has made use of this exception, and many forms of age discrimination in relation to pensions are excluded from the Equality Act 2010 (UK) under section 61(8).$^{82}$

In addition to this direct discrimination, young people are also indirectly discriminated against in relation to pension provision. For example, with the move away from DB pension schemes in the private sector, ${ }^{83}$ many DB pension schemes are now closed to new entrants. Instead, some employers are now offering their employees DC pension schemes, where pension entitlements are dependent on contributions paid and investment returns, rather than final salary. ${ }^{84}$ Younger workers are disproportionately likely to be new entrants to pension schemes, meaning they are disproportionately affected by these changes. ${ }^{85}$ Even where younger workers are entitled to join a pension scheme, there has been a progressive re-evaluation of pension benefits, which again is likely to disproportionately affect younger workers. ${ }^{86}$ At the national level, too, a

\footnotetext{
${ }^{82}$ See Equality Act (Age Exceptions for Pension Schemes) Order 2010 (UK) SI 2010/2133.

${ }^{83}$ Kilpatrick (n 49) 21.

${ }^{84}$ Thornton (n 51) 265.

${ }^{85}$ See, eg, Dumbreck v OFCOM [2012] EqLR 1164 (ET).

${ }^{86}$ For occupational pensions see, eg, Universities Superannuation Scheme, 'Employer Consultation 2015' (2015), available at: www.ussconsultation.co.uk/members/abouts.
} 
series of changes to government pensions (see part V) all operate prospectively, meaning that younger workers are likely to have lower pension entitlements than their older colleagues, and will only be able to claim a pension at a later age. There is no sign that the changes will end here: young people's pension entitlements may continue to be eroded in the years to come.

Despite this disparate impact on different age groups, there have been few claims of age discrimination in relation to pension schemes, likely because the broad exceptions to the Equality Act 2010 under the Equality Act (Age Exceptions for Pension Schemes) Order 2010 (UK) SI 2010/2133 preclude such claims in most cases. At the EU level, increases in the amount of contributions to an occupational pension scheme on the basis of age were challenged in HK Danmark $v$ Experian $A / S .{ }^{87}$ In that case, the employee's contract provided for occupational pension contributions that varied by age, as follows:

- Under 35 years of age: employee contribution 3 per cent and Experian contribution 6 per cent.

- From 35 to 44 years of age: employee contribution 4 per cent and Experian contribution 8 per cent.

- Over 45 years of age: employee contribution 5 per cent and Experian contribution 10 per cent.

The employee claimed that this was a form of age discrimination.

The Court of Justice of the European Union (CJEU) held that the Framework Directive applied to the dispute between two private parties 'on the basis of the principle of non-discrimination on grounds of age, enshrined in Article 21 of the Charter and given specific expression by Directive 2000/78' ${ }^{88}$ The employer's contributions to the pension scheme constituted 'pay' within the meaning of Article 157(2) of the Treaty on the Functioning of the European Union, and therefore fell within the scope of the Framework Directive. ${ }^{89}$ When the pension contributions were added to an employee's base salary as a form of pay, 'The fact that the overall monthly pay of younger workers is lower and, accordingly, the fact that the treatment they are afforded is less favourable, are, therefore, directly linked to age'. ${ }^{90}$ The scheme therefore constituted a difference in treatment on the basis of age.

The exception in Article 6(2) of the Framework Directive for occupational pension schemes was to be interpreted restrictively, to only cover: (1) occupational social security schemes that cover the risks of old age and invalidity; ${ }^{91}$ and (2) 'fixing ... of ages for admission or entitlement to retirement or invalidity benefits', including the 'use ... of age criteria in actuarial calculations'. ${ }^{92}$ With this restrictive interpretation,

\footnotetext{
${ }^{87}$ Case C-476/11 HK Danmark v Experian A/S [2013] CJEU 590.

88 ibid [31].

${ }^{89}$ ibid [24]-[30].

${ }^{90}$ ibid [35].

${ }^{91}$ See similarly, Case C-546/11 Dansk Jurist-og Økonomforbund $v$ Indenrigs-og Sundhedsministeriet [2014] ICR 1 [43].

${ }^{92}$ HK Danmark v Experian A/S (n 87) [44]-[49].
} 
the CJEU held that age-related increases in pension contributions did not fall within the scope of Article 6(2) of the Framework Directive. ${ }^{93}$ Therefore, the difference in treatment needed to be justified.

The employer argued that the difference in treatment was justified by two legitimate aims: (1) providing a means for all employees to build up reasonable retirement savings, by enabling older workers to build their savings over a relatively short contribution period, while allowing younger workers to have a larger proportion of their wages at their disposal; and (2) covering the risks of death, incapacity and serious illness, the cost of which increases with age. ${ }^{94}$ The CJEU held that these were capable of being legitimate aims. ${ }^{95}$ While the CJEU noted that 'it does not appear unreasonable to regard the age-related increases in contributions as enabling the aims', ${ }^{96}$ this was ultimately a matter for determination by the national court. ${ }^{97}$ This case suggests that employers will need to justify any age-based differences in contributions to social security schemes. However, it also appears that this will not be a difficult hurdle in most cases. ${ }^{98}$

Disparate treatment on the basis of age in relation to pension provision does not appear to often be the subject of legal claims, ${ }^{99}$ perhaps reflecting young workers' low levels of engagement with pension entitlements. ${ }^{100}$ The exception is in relation to judicial pensions, where the transitional provisions in the New Judicial Pension Scheme 2015 were successfully challenged as a form of age discrimination against younger judges. ${ }^{101}$ It was ultimately held that the transitional provisions were not justified as a proportionate means of achieving a legitimate aim. ${ }^{102}$ However, the broader changes wrought by the scheme - which impose higher individual contributions on judges, and revert to a career-average defined benefit pension, rather than a final salary pension - were not challenged. Thus, the intergenerational fairness of pension reforms remains a live and challenging issue.

\footnotetext{
93 ibid [54].

94 ibid [58]-[59].

95 ibid [62].

96 ibid [66].

${ }^{97}$ ibid [68].

${ }^{98}$ Though see Pattersonv Merseyside Police Authority (2009) ET 2106251/08, where it was held that there was no legitimate aim to support the pension policy other than cost saving.

${ }^{99}$ Though see $R$ (on the application of Harvey) v Haringey LBC [2018] EWHC 2871 (Admin), [2019] Pens LR 3; British Gurkha Welfare Society v Ministry of Defence [2010] EWCA Civ 1098; $R$ (on the application of Smith) $v$ Secretary of State for Defence [2004] EWHC 1797 (Admin), [2005] 1 FLR 86. In relation to welfare payments, see $R$ (on the application of Reynolds) $v$ Secretary of State for Work and Pensions [2002] EWHC 426 (Admin).

${ }^{100}$ See National Association of Pension Funds, 'Workplace Pensions Survey' (2013); H Osborne, 'Young Workers "Face Grind to 70s"' The Guardian (14 June 2005), available at: www.theguardian.com/ money/2005/jun/14/business.pensions.

${ }^{101}$ See Ministry of Justice, 'New Judicial Pension Scheme: Scheme Guide’ (2014).

${ }^{102}$ McCloud v Lord Chancellor (2017) ET 2201483/2015; Lord Chancellor v McCloud [2018] EWCA Civ 2844, [2019] Pens LR 12. In the Employment Tribunal, the provisions were held to be both not pursuing a legitimate aim, and not proportionate. In the Employment Appeal Tribunal, it was held that there was a legitimate aim, but that the provisions were not proportionate. In the Court of Appeal, the decision of the Employment Tribunal was upheld. Permission to appeal to the Supreme Court was refused. A similar challenge to the transitional provisions of the New Firefighters' Pension Scheme was also upheld.
} 


\section{B. National and International Portability}

For Andrietti, 'pension mobility' is defined as the 'capacity of workers covered by an occupational pension plan to preserve the actuarially fair value of their accrued rights while moving to a different employer and possibility to a different pension scheme'. ${ }^{103}$ However, in a globalised labour context, pension mobility could be defined more broadly, to extend to pensions other than occupational pensions, and to encompass moving to a different country. For d'Addio and Cavalleri, then, portability is the possibility of acquiring and keeping social benefit entitlements and/or social rights when workers are mobile for work reasons. ${ }^{104}$ This might encompass a change of employer within a country (job-to-job mobility) or a change of employer and a change of country (country-to-country mobility). ${ }^{105}$ Thus, portability might be defined as the ability to preserve, maintain and transfer benefits from one country to another and between localities in a country (spatial portability); between jobs; and between members in a household (social portability). ${ }^{106}$ Given the growth of migrant work, we must be concerned with both 'cross-border' portability, ${ }^{107}$ and 'within-border' portability. ${ }^{108}$

We can posit three key criteria to evaluate the fairness and efficiency of pension portability provisions between countries. First, there should be no benefit disadvantage for the pensions of migrants: that is, migrants should not be disadvantaged when they move between countries. Second, there should be fairness for both countries, particularly in relation to their financial responsibilities for departing and arriving migrants. Third, there should be bureaucratic effectiveness, so that there is a limited administrative or bureaucratic burden for institutions or migrants themselves. ${ }^{109}$

While straightforward in theory, these criteria are fiendishly difficult to achieve in practice. Pension portability can be secured through a variety of measures. First, governments can enact unilateral measures (that is, national policies or laws) that facilitate portability. ${ }^{110}$ Second, governments can enter into bilateral agreements between different countries, to facilitate movement. ${ }^{111}$ Traditionally, these intergovernmental agreements are the key means of securing portability, though the agreements vary significantly in their scope and terms. ${ }^{112}$ Often, however, the agreements will remove or modify residency or nationality requirements for claiming social benefits, or facilitate cooperation between countries. ${ }^{113}$ Third, governments could enter into

\footnotetext{
${ }^{103} \mathrm{~V}$ Andrietti, 'Portability of Supplementary Pension Rights in the European Union' (2001) 54 International Social Security Review 59, 60.

104 d'Addio and Cavalleri (n 30) 346.

105 ibid.

${ }^{106} \mathrm{~N}$ Taha et al, 'How Portable is Social Security for Migrant Workers?' (2013) 573 ISS Working Paper Series/General Series 1, 7-8.

${ }^{107}$ Andrietti (n 103) 62.

${ }^{108}$ cf B Lu and J Piggott, 'Meeting the Migrant Pension Challenge in China' (Portability of Social Benefits: The Economics of a Critical Topic in Globalisation, Venice, August 2012), available at: www.cesifo-group. de/link/vsi12-psb_lu.pdf.

${ }^{109}$ Holzmann and Koettl (n 29) 9.

${ }^{110}$ Taha et al (n 106) 10.

111 ibid. On bilateral agreements and migration generally, see P Wickramasekara, Bilateral Agreements and Memoranda of Understanding on Migration of Low Skilled Workers: A Review (Geneva, ILO, 2015).

112 d'Addio and Cavalleri (n 30) 347.

113 Taha et al (n 106) 10.
} 
multilateral agreements, to facilitate mobility within a region or group of countries, as has occurred in the EU. Thus, while governments have options to secure pension portability, this will require intergovernmental and international cooperation, within a common framework of normative goals. Understandably, this is hard to achieve in practice.

\section{TRENDS IN PENSION REFORM}

With these normative criteria in mind, it is illuminating to consider how pension reform is actually occurring in practice. Pension reform can shift provision in two broad directions: first, by moving towards stronger solidarity, using regulation to secure welfare; or, second, by moving towards privatisation and individualisation of pension provision. In reality, most pension reforms incorporate a mix of these trends. ${ }^{114}$ For example, according to Ebbinghaus and Whiteside, there has been a general push to privatise pensions in Europe, both to secure the sustainability of pension systems, and to reduce national debt. However, lacklustre investment performance in pension funds has also led to a renewed push for regulation:

The uneven performance of funded pensions, particularly since 2001, has fostered political pressure for more state intervention: to contain costs, remove discrepancies, promote transparency and offer guarantees. The objective can appear less pension privatization than a regulation-based 'colonization' of private providers for policy purposes. ${ }^{115}$

Thus, the pendulum continues to swing between privatisation and (re)regulation of pensions, as public sentiment and political factors drive reform in both directions.

Where pension reform is undertaken, it generally manifests in four key ways. First, we can increase the age at which pension benefits can be drawn, reflecting increased life expectancy and the growing number of 'good years' in old age for many older workers. In the UK, the SPA will increase to 67 years of age by $2028,{ }^{116}$ saving the government around $£ 60$ billion between $2026-27$ and $2035-36 .{ }^{117}$ This is likely to disproportionately affect blue-collar workers and those in physically intensive work, as it pushes individuals to remain in employment for a longer period. Remaining in work is most likely to be viable for middle-class, white-collar workers in physically undemanding positions. Thus, increasing pension ages may not ensure intragenerational fairness, though it may secure intergenerational fairness consistent with a new understanding of the intergenerational contract.

Second, we can decrease the quantum of pension benefits that are payable, including by changing the formula by which pensions benefits are calculated. In the UK, for example, the move to a single-tier, flat-rate 'new State Pension' for those retiring

\footnotetext{
${ }^{114}$ P Frericks et al, 'Toward a Neoliberal Europe? Pension Reforms and Transformed Citizenship' (2009) 41 Administration \& Society 135.

${ }^{115} \mathrm{~B}$ Ebbinghaus and N Whiteside, 'Shifting Responsibilities in Western European Pension Systems: What Future for Social Models?' (2012) 12 Global Social Policy 266, 268.

${ }^{116}$ HM Treasury and HM Parliament, Autumn Statement 2011 (London, The Stationery Office, 2011) 23.

117 ibid 6.
} 
from April 2016 (rather than the former basic State Pension and earnings-based Additional State Pension) may provide a lower level of pension entitlement for many workers, though the government denied that anyone would be worse off. ${ }^{118}$ Further, since April 2017, entitlement to a full state pension in the UK requires 35 years of National Insurance contributions, rather than the previous 30 years. ${ }^{119}$ Depending on how a reduction of the quantum of pension benefits is implemented in practice, this approach could jeopardise the adequacy of income for individuals in retirement, particularly for those with few other savings to complement their pension payments. It may lead to an increase in the number of pensioners in poverty, and increasing demand for other government services and support. Thus, this reform may jeopardise adequacy of income for the elderly, and may increase government expenditure in other areas. It is also likely to disproportionately affect those with lower pension entitlements, where any reduction will constitute a larger proportion of their overall income. Thus, it may not secure intragenerational fairness, and may indirectly affect the sustainability of government expenditure.

Third, it is possible to increase government, individual and/or employer contributions to the pension system, for current and/or future members, to increase the level of funding in the pension system. Depending on the extent to which a pension system is underfunded, this may or may not address the fundamental disparity between pension benefits and contributions: the scale of underfunding may mean increased contributions make little difference to overall viability. Thus, it may not be effective to ensure the sustainability of the pension system. Further, if later generations are making larger contributions, only to receive smaller pension payments in later life, this may jeopardise intergenerational fairness. The extent to which it is seen as 'fair' that one generation subsidises the retirement of another is likely to be historically and culturally contingent. However, in the context of growing youth unemployment, stagnating wages and precarious work among younger generations, imposing higher contributions on younger workers is unlikely to be seen as fair or appropriate, particularly if this is accompanied by a reduction in future benefits.

Relatedly, we could encourage greater individual saving for retirement, reducing the burden on government and organisational pension systems. This has been modelled in the UK to some extent through the introduction of pension auto-enrolment; and in Australia through the introduction of compulsory superannuation. However, those who are most likely to be able to make provision for their own retirement (middle- and upper-income earners) likely already have plans in place to finance their retirement, including through other investment structures and/or personal pension plans. Those who would benefit from additional savings in retirement (particularly lower-income earners) may not have sufficient resources to invest in other saving vehicles. Indeed, the increase in individual debt, including credit card debt, indicates that many individuals are unable to maintain their current obligations, let alone save for the future. This is exacerbated by the trend towards precarious work, particularly for younger workers.

\footnotetext{
118 'State Pension: “Only 45\%” to Get Full New Payout' BBC News (12 January 2015), available at: www. bbc.co.uk/news/business-30777166.

119 ibid.
} 
Fourth, for government pensions, we could increase levels of taxation and/or redirect taxation income towards the payment of pension benefits. This will likely redirect income away from other important services, particularly in an era of austerity where government services have already been significantly cut back. This may again disproportionately affect younger generations, who may be more likely to use other government services (such as schools).

Thus, while a range of potential pension reforms could be pursued, they are all attended by risks and challenges, particularly in securing intergenerational and intragenerational fairness, sustainability and adequacy of income. Preferred models of reform are likely to be nationally and temporally contingent. For example, Jaime-Castillo has found that individuals' preferred models of pension reform are largely dependent on their approach to solidarity:

[I]ndividuals who adhere to universalistic [conceiving of pensions as a universal social right] or conservative principles [seeing pensions as for maintaining status] are more in favour of increasing contributions in order to maintain the level of pensions, whereas they oppose a postponement of retirement age. In contrast, those who adhere to liberal [believing that pensions should match contributions] or familistic principles [seeking the family as obligated to support retirement] are against increasing contributions and prefer extending retirement age. ${ }^{120}$

Despite this diversity, attitudes to pension reform are surprisingly similar across the EU Member States, particularly in the general level of pessimism in relation to the impact of ageing on the sustainability of pension systems. ${ }^{121}$ There is a general preference in both Eastern and Western Europe to raise taxes and extend working life, rather than to reduce pension benefits. ${ }^{122}$

Overall, though, these reforms do not help to address the more fundamental challenges to pension systems from the changing nature of work: a new approach is required, that balances these tensions and normative criteria.

\section{CONCLUSION}

As the world of work changes and evolves, the link between (stable, long-term) employment and old age pensions is becoming increasingly precarious. Challenges to established pension systems - particularly those from job mobility, international mobility, work precarity, gender pension disparities and demographic ageing - reveal that established models of accruing pension rights are not sustainable into the future.

We need a new approach, which disentangles pension rights from work status. This may, then, support calls for a universal citizens payment or form of basic income,

\footnotetext{
${ }^{120}$ AM Jaime-Castillo, 'Public Opinion and the Reform of the Pension Systems in Europe: The Influence of Solidarity Principles' (2013) 23 Journal of European Social Policy 390, 393-94.

${ }^{121} \mathrm{~K}$ Velladics et al, 'Do Different Welfare States Engender Different Policy Preferences? Opinions on Pension Reforms in Eastern and Western Europe' (2006) 26 Ageing and Society 475.

122 ibid.
} 
which is not contributory or dependent on work status. ${ }^{123}$ This would help to ensure adequacy of income into old age, address job precarity, ensure intergenerational and intragenerational fairness, and collectivise the risks of old age and demographic change.

That said, providing everyone with the same payment will not achieve substantive equality. ${ }^{124}$ While recognising that pensions have never been substantively fair, ${ }^{125}$ moving towards a system that values fairness is still a normatively desirable goal. Going further, though, it is unclear how this sort of model might be adapted for an internationally mobile workforce, particularly given the potential political and economic costs of a universal basic income. ${ }^{126}$ While these questions have no easy answers, the difficulties facing pension systems mean they must be grappled with.

\footnotetext{
${ }^{123}$ D Arthur, 'Basic Income: A Radical Idea Enters the Mainstream' (Parliament Library Research Paper, November 2016), available at: www.aph.gov.au/About_Parliament/Parliamentary_Departments/ Parliamentary_Library/pubs/rp/rp1617/BasicIncome\#_Toc467232178.

${ }^{124}$ See ibid.

${ }^{125} \mathrm{eg}$, the UK state pension was originally introduced in 1908 for only the 'very old, the very poor, and the very respectable': L Hannah, Inventing Retirement: The Development of Occupational Pensions in Britain (Cambridge, Cambridge University Press, 1986) 15-16; P Thane, Old Age in English History: Past Experiences, Present Issues (Oxford, Oxford University Press, 2000) 225, which would have excluded most members of the working class who would not live to be 'very old'.

${ }^{126}$ Arthur (n 123).
} 


\section{University Library}

\section{- M M I N E R VA A gateway to Melbourne's research publications}

Minerva Access is the Institutional Repository of The University of Melbourne

Author/s:

Blackham, A

Title:

Pensions and the Modern Workforce

Date:

2020

Citation:

Blackham, A. (2020). Pensions and the Modern Workforce. Agnew, S (Ed.). Davies, P (Ed.). Mitchell, C (Ed.). Pensions: Law, Policy and Practice, (1), pp.271-292. Hart Publishing.

Persistent Link:

http://hdl.handle.net/11343/242015 